\title{
Can Existing Social Media Encourage Health and Care Co-production?
}

\author{
Hadi Daneshvar \\ The University of Edinburgh \\ School of Informatics \\ h.daneshvar@ed.ac.uk
}

\author{
Stuart Anderson \\ The University of Edinburgh \\ School of Informatics \\ soa@staffmail.ed.ac.uk
}

\begin{abstract}
The Future of health in EU faces the triple challenges of ageing, fiscal restriction and inclusion. Coproduction offers ways to manage informal care resources to help cater for the growing needs of elderly people. We investigate the uses of Social media (SM) as an enabler of co-production in health and care. We conducted a qualitative study using interviews and online observations. We found that particular types of SM are currently used to enable co-production through coordination and communication across boundaries. Particularly, Twitter and Facebook are used to connect carers, disseminate information and invite volunteers. However there are still many other types of SM which are rarely used in this sector due to their limitations. Nevertheless, carers showed interest in using systems which help them to engage people in shaping services, sharing experiences and encouraging care activities.
\end{abstract}

Social Media; e-Health; Co-production.

\section{INTRODUCTION}

The future of health in the European Union faces the triple challenges of ageing, fiscal restriction and inclusion [1]. In the UK, the number of elderly people will increase to 6.6 million in the next 25 years. In Scotland, people aged over 74 are projected to increase most radically by $82 \%$ by 2035. These statistics show that the needs of elderly people are growing and that there is an increased requirement for carers. The population of informal carers account for around $10 \%$ of the population of the UK $(62 \mathrm{M})$. It is projected that this number will increase to 9 million (around 12\% of 73.2M population) in the next 25 years [2]. The current value of care (Table 1) is worth an estimated £119bn per year - almost equal to NHS England's annual budget [3].

Table 1- Number of carers in The United Kingdom, 2011

\begin{tabular}{|l|c|}
\hline \multicolumn{1}{|c|}{ Regions } & Number of Carers \\
\hline England & $5,430,016$ \\
\hline Scotland & 492,231 \\
\hline Northern Ireland & 213,980 \\
\hline Wales & 370,230 \\
\hline UK Total & $6,506,457$ \\
\hline
\end{tabular}

An important challenge thereof is how to provide resources for the health and care of elderly people in future. In this respect, we have a big pool of informal carers which need to be managed to meet existing and future care needs. Co-production offers ways to manage informal care resources. The full participation of informal carers in the coproduction of health and care has the potential to play a significant role in the sustainability of health and care delivery. A pressing issue is how to coordinate this massive resource with the formal health and care system to enable true coproduction of health and care.

Increasingly, e-health is seen as a mean to reshape healthcare systems [4]. In particular, social media (SM) are seen as a critical enabler for coproduction [5]. Communication is a key element in co-production, enabling coordination across various boundaries. SM cuts across boundaries and is well understood.

\section{OBJECTIVE}

Our study investigates the current and possible future for SM as an enabler of co-production in health and care. To achieve these aims, two main sets of questions are asked:

- what are the current uses of SM in health and social care? 
- How can SM be reshaped to enable (and reshape) health and care co-production?

We consider a typology of opportunities and limitations of SM for health and care. Existing health and care service bundles with (1) existing or (2) new SM tools. New health and care service bundles with (3) existing or (4) emerging SM tools. In this part of the research, we focused on the first type "Existing health and care service with existing SM tools".

Table 2 - SM and Health and care

\section{Health and Care}

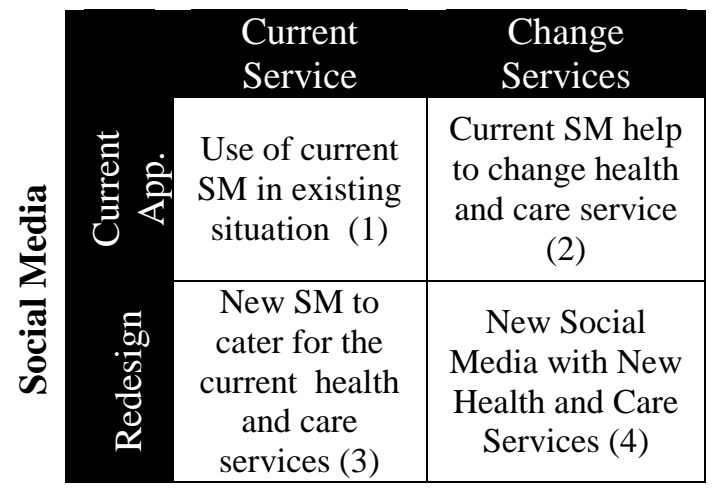

\section{METHODOLOGY}

We conducted a qualitative study investigating the socio-technical aspects of the current and possible future uses of SM by different organizations and groups as an enabler of co-production. We used purposeful sampling to select organisations and groups who were providing care services to elderly people. We used a combination of interviews and online observations of groups and activities to collect data.

We used interviews as the main method of data collection to answer these questions. We have conducted 12 in-depth interviews focusing on the above aspects and observed the activities of 10 groups / organisations in different SM environments.

\section{PRELIMINARY RESULTS}

Table 2 shows the outline of our findings. Our findings showed very limited use of social media in elderly healthcare services. We found that many types of social media are very rarely used in this sector. The main reason for not using SM were reported as:

1- Low skills and lack of awareness of users, particularly professional carers;

2- High costs and effort needed to update and monitor the content of the SMs;

3- Professional carers are not familiar with the professional use of technology. Although many carers showed interest - and some were even using SM for personal communication - they had very limited knowledge of how these systems be can used to achieve benefits in the course of care for elderly people;

Table 3 - Social media use by different groups

\begin{tabular}{|c|c|c|c|}
\hline Existing SM & Professional Carers & Voluntary organizations & Private Sectors \\
\hline $\begin{array}{l}\text { Social Networking } \\
\text { (FB.) }\end{array}$ & $\begin{array}{l}\text { - Company use } \\
\text { - Informal communication } \\
\text { between supervisors and } \\
\text { carers }\end{array}$ & $\begin{array}{l}\text { - Broadcast information } \\
\text { - Promote Services for carers and families } \\
\text { - Promote activities for carers and patients } \\
\text { - Invite volunteers (carers) to contribute to activities } \\
\quad \text { for elderly people } \\
\text { - Connect with other organizations }\end{array}$ & $\begin{array}{l}\text { - Private Group } \\
\text { - Co-service }\end{array}$ \\
\hline $\begin{array}{l}\text { Micro-Blog } \\
\text { (Twitter) }\end{array}$ & - Broadcasting of information & $\begin{array}{l}\text { - Communicate and connect with other organizations } \\
\text { - Receive updates about events } \\
\text { - Communicate with wider people } \\
\text { - Fundraising } \\
\text { - Broadcast information } \\
\text { - Promote Services for carers and families } \\
\text { - Promote activities for carers and patients } \\
\text { - Invite volunteers (carers) to contribute to activities } \\
\text { for elderly people }\end{array}$ & \\
\hline Blog & $\begin{array}{l}\text { - Not familiar and not used } \\
\text { widely. }\end{array}$ & $\begin{array}{l}\text { - Only used by very large volunteer organizations } \\
\text { - Patients and families share stories and experiences }\end{array}$ & \\
\hline Forum & $\begin{array}{l}\text { - Not familiar and not used } \\
\text { widely. }\end{array}$ & - Online forum not used & \\
\hline Website & $\begin{array}{l}\text { - Promote and present the } \\
\text { company }\end{array}$ & - Website used as a news page only & \\
\hline
\end{tabular}


4- Problems in accessing to the online resources because of low level of skills and confidence, in particular for elderly people.

5- Carers and professional carers have security concerns in using SM to share information.

\section{CONCLUSION \& FUTURE WORK}

We can conclude that:

- Existing SM (Twitter \& FB) are currently used to enable co-production

- Twitter and Facebook are used to connect carers, disseminate information and invite volunteers to take part in care activities.

- In some organisations, carers respond with SM to provide co-delivery of services

- Difficulties in use of SM: Low skills awareness; high costs and effort needed to update and monitor the contents of these SMs; Professional carers not familiar with professional use of technology; Problems in accessing to the online resources; Security and confidentiality concerns in using SM to share information; current SMs do not cater for all their needs

- Carers interested in having a particular system designed for their specific uses

Our findings suggest we need to design a specific SM system that covers the particular needs and concerns of carers in order to coproduce health and care

In the next steps of this project, we aim to identify new services (e.g. workforce co-ordination and cooperative organisations) which could be offered with existing SM. Then, we will explore the possibilities for designing a new SM to cater for existing needs as well as the new services required.

\section{REFERENCES}

[1] Carretero S, Stewart J, Centeno C, Barbabella F, Schmidt A, Lamontagne-Godwin F, Lamura G (2012) Can technology-based services support long-term care challenges in home care? Analysis of evidence from social innovation good practices across the EU: CARICT project summary report, JRC a scientific and policy report JRC77709. Publications Office of the European Union, Luxembourg

[2] Dilnot A. Fairer Care Funding: The Report of the Commission of Funding of Care and Support. Vol. 1. London: The Dilnot Commission; 2011

[3] Facts about carers 2012. Policy briefing. London: Carers UK. Available at: www. carersuk. org/media/k2/attachments/Facts_about_carers_ Dec_2012.pdf

[4] Gaddi A, Capello F, Manca M (2014) eHealth, care and quality of life. Springer, Milan, Dec 2013

[5] Kuan-Yu Lin, Hsi-Peng Lu, Why people use social networking sites: An empirical study integrating network externalities and motivation theory, Computers in Human Behavior, Volume 27, Issue 3, May 2011, Pages 1152-1161 